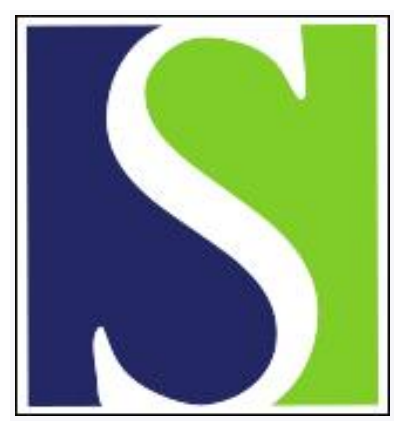

Scand J Work Environ Health 1981;7(4):302-309

https://doi.org/10.5271/sjweh.2544

Issue date: Dec 1981

On the interaction between occupational arsenic exposure and smoking and its relationship to lung cancer.

by Pershagen $\mathrm{G}$, Wall S, Taube A, Linnman L

Key terms: arsenic; arsenic exposure; cancer; interaction; lung; lung cancer; occupational arsenic exposure; occupational exposure; smelter; smoking; sulfur dioxide

This article in PubMed: www.ncbi.nlm.nih.gov/pubmed/7347915

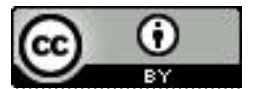




\title{
On the interaction between occupational arsenic exposure and smoking and its relationship to lung cancer
}

\author{
by Göran Pershagen, MD, ${ }^{1}$ Stig Wall, PhD, ${ }^{2}$ Adam Taube, $\mathrm{PhD},{ }^{3}$ \\ Lars Linnman, $\mathrm{BSc}^{1}$
}

\begin{abstract}
PERSHAGEN G, WALL S, TAUBE A, LINNMAN L. On the interaction between occupational arsenic exposure and smoking and its relationship to lung cancer. Scand $j$ work environ health 7 (1981) 302-309. The interaction between occupational arsenic exposure and tobacco smoking and its relationship to lung cancer mortality among 228 deceased Swedish copper smelter workers was studied with the case-referent technique. Arsenic exposure was assessed via detailed company records, and information on smoking habits was gathered from the next of kin. The age standardized rate ratio for death from lung cancer was 3.0 for arsenic-exposed nonsmokers and 4.9 for smokers without occupational arsenic exposure in relation to nonarsenic-exposed nonsmokers. For arsenic-exposed smokers the rate ratio was 14.6, indicating a multiplicative effect of the two exposures. Eighty-five percent of all deaths from lung cancer among the smelter workers could be "explained" by arsenic exposure and/or smoking. The interaction between arsenic and smoking suggests that a strong preventive effect on lung cancer incidence could be obtained by decreasing either one of the exposures or by disaggregating them.
\end{abstract}

Key terms: smelter, sulfur dioxide.

Exposure to inorganic arsenic compounds has been associated with an increased mortality from lung cancer among copper smelter workers $(12,25,33)$, pesticide production workers $(9,15,21)$, and vintners $(8,29)$. In several of the studies positive dose-response relationships were indicated. Investigations on Swedish copper smelter workers have revealed an increased risk of lung cancer (23), especially among workers exposed to arsenic $(2,34)$.

The interaction between tobacco smoking and occupational exposures can sometimes be fit to a multiplicative model, in which the effect, eg, increase in lung can-

1 Department of Environmental Hygiene, Karolinska Institute and National (Swedish) Institute of Environmental Medicine, Stockholm, Sweden.

2 Department of Social Medicine, University of Umeå, Umeå, Sweden.

3 Department of Statistics, University of Uppsala, Uppsala, Sweden.

Reprint requests to: Dr G Pershagen, National Institute of Environmental Medicine, PO Box 60 208, S-104 01 Stockholm, Sweden. cer incidence, on workers who are smokers can be estimated by the multiplication of effects in nonexposed smokers and exposed nonsmokers. This type of interaction has been observed in asbestos factory and insulation workers $(4,31)$, and in uranium ore miners (1). In other instances the multiplicative model is not applicable, eg, among zinc-lead miners (3) and workers exposed to chloromethylethers (35). Two studies on American copper smelter workers exposed to arsenic did not give evidence of a positive interaction between smoking and smelter employment (not further specified) on lung cancer mortality $(25,26)$. However, no detailed analysis of the arsenic-tobacco smoking interaction was performed.

A peculiarity with arsenic carcinogenicity is the discrepancy between epidemiologic and experimental data. Animal carcinogenicity tests have been negative except for some preliminary data indicating a role of arsenic in the development of lung cancer (10) and leukemia (20). Arsenic is not mutagenic in bacterial tests $(13,28)$. 
On the other hand, there are indications, from different experimental systems, that arsenic may interfere with deoxyribonucleic acid (DNA) repair, and therefore a cocarcinogenic effect is possible $(11,27)$.

The purpose of the present investigation was to elucidate the arsenic-tobacco smoke interaction among workers from a large Swedish copper smelter. It was anticipated that the results would give practical guidance for minimizing the risks associated with occupational exposure to arsenic, as well as provide insight into the mechanisms of arsenic carcinogenicity.

\section{Methods}

\section{Source of subjects}

The study was performed according to the case-control or case-referent technique within a cohort. The cohort included all male workers employed at least three months at the Rönnskärsverken copper smelter since the start of operations in 1928 until 1 January 1967 (34). It consisted of 3,958 subjects who were followed until 1 January 1977 , and all but $1 \%$ were traced. Data on the causes of death among the 953 workers who had died before this date were obtained from the National Register on Causes of Death. This register contains information from death certificates, which have been shown to be of high validity for most diagnoses (6).

The cases constituted all men who had died from cancer of the trachea, bronchus, or lung (International Classification of Diseases 162, eighth revision), ie, a total of 76 subjects. Two referents were chosen for each case among deceased workers in the cohort who had not died from cancer of the trachea, bronchus, or lung. The referents were matched to the cases according to year of birth. Altogether the group of cases and referents included 228 subjects.

\section{Source of exposure information}

The information on occupational exposure was gathered from company records, which had been kept since the start of operations at the smelter in 1928. The records contained detailed information on the time spent in various workplaces at the smelter by each worker (34).

The assessment of arsenic exposure was based on a safety engineer's estimations of exposure levels in each department during different time periods (19). Exposure to sulfur dioxide $\left(\mathrm{SO}_{2}\right)$, which often occurred together with arsenic, was assessed in a similar way. Actual measurements were few however; in 1954 it was reported that the average concentrations of airborne arsenic ranged from 0.06 to $2 \mathrm{mg} / \mathrm{m}^{3}$, while those of $\mathrm{SO}_{2}$ ranged from 15 to $300 \mathrm{mg} / \mathrm{m}^{3}$ at the roasters and copper furnaces and in the converter hall (14). The workers were classified into different categories according to their estimated exposure to arsenic and $\mathrm{SO}_{2}$, and the time trend in exposure levels was also taken into account:

a. Roaster workers: More than six months of work in the gas purifier or roaster departments. Both arsenic and $\mathrm{SO}_{2}$ exposure was high for this group.

b. High arsenic: More than six months of work in the arsenic metal, arsenic refining, arsenic salt, building, electric, machine, or selenium departments, excluding roaster workers. The arsenic exposure was high in this group, but lower than for the roaster workers, and the $\mathrm{SO}_{2}$ exposure was substantially lower than for the roaster workers.

c. High $\mathrm{SO}_{2}$ : More than six months of work in the anode furnace, converter, copper furnace, or sulfur departments, excluding roaster workers and workers in the high arsenic category. The $\mathrm{SO}_{2}$ levels were as high in these workplaces as at the roasters, but the arsenic levels were substantially lower.

Arsenic exposure primarily occurred at the workplaces included in the roaster worker, high arsenic, and high $\mathrm{SO}_{2}$ exposure categories. Consequently, the workers in these categories were grouped together in the "arsenic exposed" category. The major remaining worksites at the smelter, where subjects in the reference category (no arsenic exposure) had worked, included the battery factory, central laboratory, coal crusher, copper foundry, deliv- 
Table 3. Tobacco consumption among smoking smelter workers in different exposure categories.a

\begin{tabular}{|c|c|c|}
\hline Fynncure cat & Numbar & Daily tobacco consumption ${ }^{b}(\mathrm{~g})$ \\
\hline & & Standard deviation \\
\hline
\end{tabular}

No arsenic exposure

\begin{tabular}{|c|c|c|c|}
\hline $\begin{array}{l}\text { Cases } \\
\text { Referents }\end{array}$ & $\begin{array}{l}24 \\
49\end{array}$ & 12.3 & 9.7 \\
\hline \multicolumn{4}{|c|}{ igh sulfur dioxide exposure } \\
\hline $\begin{array}{l}\text { Cases } \\
\text { Referents }\end{array}$ & $\begin{array}{r}9 \\
21\end{array}$ & 10.9 & 13.3 \\
\hline \multicolumn{4}{|c|}{ igh arsenic exposure } \\
\hline $\begin{array}{l}\text { Cases } \\
\text { Referents }\end{array}$ & $\begin{array}{l}18 \\
19\end{array}$ & 14.7 & 8.7 \\
\hline \multicolumn{4}{|c|}{ oaster workers } \\
\hline $\begin{array}{l}\text { Cases } \\
\text { Referents }\end{array}$ & $\begin{array}{l}17 \\
11\end{array}$ & 11.5 & 10.0 \\
\hline
\end{tabular}

a For 11 of the 168 subjects reported to be daily smokers for at least $2 \mathrm{a}$, it was not possible to get data on consumption.

b Computed by adding cigarettes (assuming $1 \mathrm{~g}$ tobacco/cigarette) and pipe tobacco (calculated from data on weekly consumption).

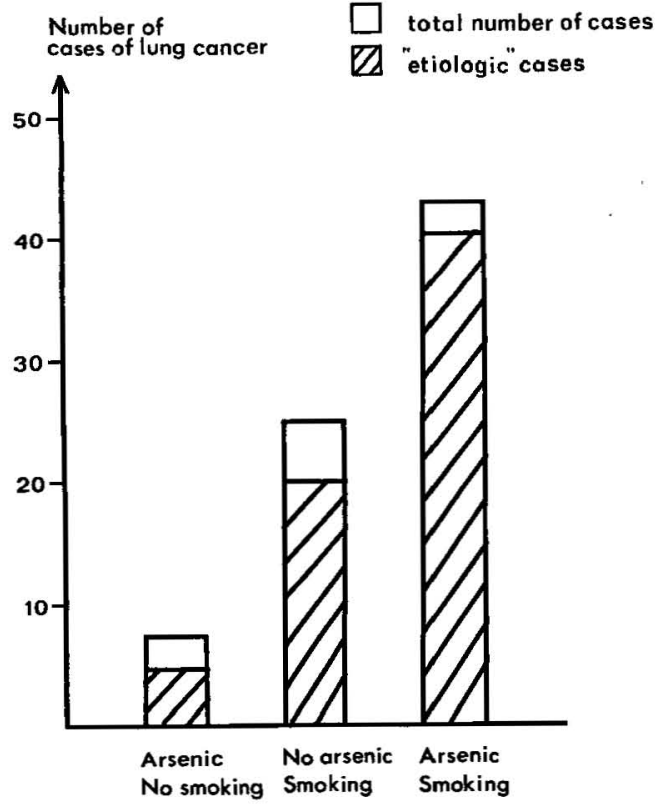

Fig 1. Etiologic fraction of lung cancer cases among smelter workers exposed to arsenic and/or smokers.

etiologic fraction of $67 \%$, ie, 4.7 out of the total of 7 lung cancer cases in this group. Similarly, for a total of 24 cases of lung cancer among the smokers not exposed to arsenic, 19.2 may be attributed to smoking, and the etiologic fraction of $93 \%$ of the arsenic-exposed smokers corre-

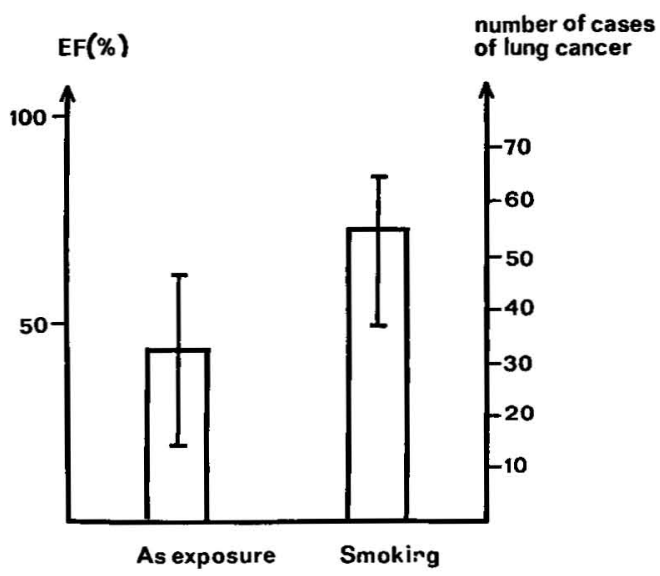

Fig 2. Etiologic fraction (EF) of deaths due to lung cancer associated with arsenic (As) exposure and smoking. Bars indicate approximate $95 \%$ confidence intervals.

sponds to 41 out of 43 cases. Altogether this makes 64.9 "etiologic" cases ie, which not would have occurred in the absence of exposure.

Fig 2 shows the relative importance of arsenic exposure and smoking for the whole population of smelter workers. 


\title{
Scandinavian Journal of
}

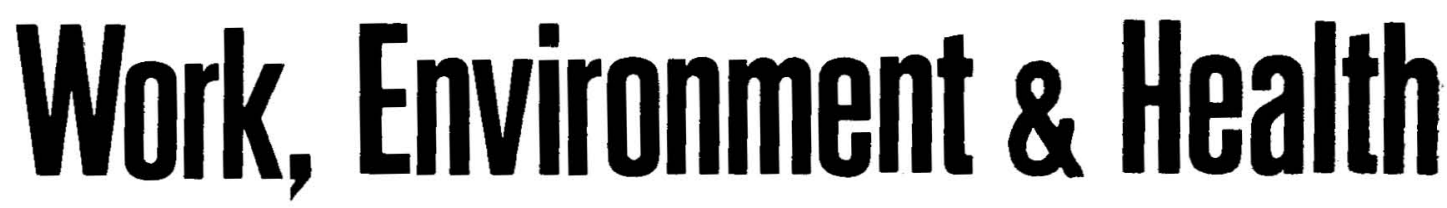

\author{
Volume 7, 1981 - CONTENTS
}

Editor in chief: Sven Hernberg, Helsinki

Assistant editor in chief: Markku Nurminen, Helsinki

Technical editor: Georgianna Oja, Helsinki

\section{Co-editors}

Axel Ahlmark, Umeå

Børge Fallentin, Copenhagen

\section{Editorial board}

Antero Aitio, Helsinki

Kari Alanko, Lahti

Ib Andersen, Copenhagen

Olav Axelson, Linköping

Lars Belin, Göteborg

Maths Berlin, Lund

Karl-Heinz Cohr, Copenhagen

Gunnar Damgaard Nielsen, Copenhagen

Erik Dybing, Oslo

PO Fanger, Copenhagen

Francesco Gamberale, Stockholm

Gideon Gerhardsson, Stockholm

Helena Hänninen, Helsinki

Matti Hakama, Tampere

Bo Holma, Copenhagen

Jörgen Jahr, Oslo

Martti J Karvonen, Helsinki

Sverre Langård, Porsgrunn
Irma Åstrand, Stockholm

Tor Norseth, Oslo

Gunnar Mowé, Oslo

Gunnar Nordberg, Umeá

Magnus Piscator, Stockholm

Jorma Rantanen, Helsinki

Christoffer Rappe, Umeå

Vesa Riihimäki, Helsinki

Kåre Rodahl, Oslo

Ragnar Rylander, Göteborg

Jorma Saari, Tampere

Anna Maria Seppäläinen, Helsinki

Staffan Skerfving, Lund

Lennart Sundell, Orebro

Ole Svane, Copenhagen

Åke Swensson, Stockholm

Gunnar Thiringer, Göteborg

Sakari Tola, Helsinki

Ulf Ulfvarson, Stockholm

Harri Vainio, Helsinki

\section{Publishers}

Institute of Occupational Health, Finland

National Board of Occupational Safety and Health, Sweden

Swedish Medical Society, Section for Environmental Health, Sweden

Work Research Institutes, Norway

The Working Environment Fund, Denmark

Address: Haartmaninkatu 1, SF-00290 Helsinki 29, Finland

Subscription for 1981 ( 4 regular issues plus supplements): FIM 250.00 surface mail FIM 300.00 air mail 


\section{CONTENTS}

\section{Volume 7, Number 1, March 1981}

"Human response to controlled levels of combinations of sulfur dioxide and inert

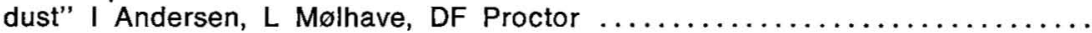

"Methyl chloride and diazepam effects on performance" V Putz-Anderson, JV Setzer,

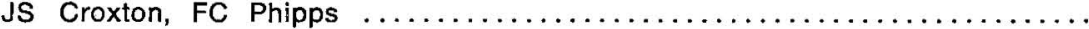

"A study of chromosomal aberrations in miners exposed to diesel exhausts" I Nor-

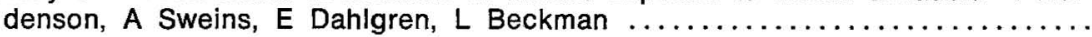

"Felling work, low-back pain and osteoarthritis" E Sairanen, L Brüshaber, M Kaskinen

"Changes in rat liver microsomal cytochrome P-450 and enzymatic activities after the inhalation of $n$-hexane, xylene, methyl ethyl ketone and methylchloroform for four weeks" R Toftgård, OG Nilsen, JA Gustafsson ..................

"A rapid method for the selective analysis of total urinary metabolites of inorganic

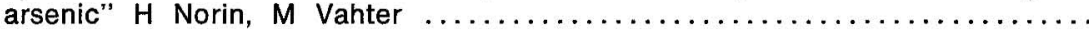

"Distribution and elimination of ${ }^{14} \mathrm{C}$-styrene in rat" $\mathrm{A}$ Carlsson $\ldots \ldots \ldots \ldots \ldots \ldots$.

"Distribution and elimination of ${ }^{14} \mathrm{C}$-xylene in rat" $\mathrm{A}$ Carlsson $\ldots \ldots \ldots \ldots \ldots \ldots$

"Interferences in the spectrophotometric S-diphenylcarbazide determination of environmental hexavalent chromium in a chromium and zinc plating plant" G Carelli,

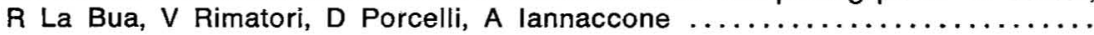

Letter to the Editor: "Video computer terminals and occupational dermatitis" V Lin-

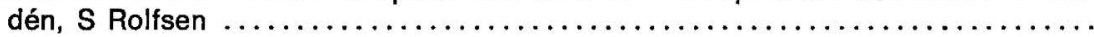

Letter to the Editor: "A Swedish cancer-environment register available for research"

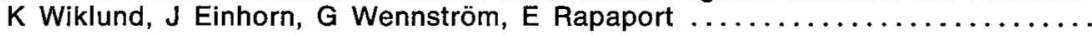

Book review: Recommended health-based limits in occupational exposure to heavy

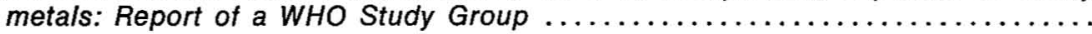

Book review: Safety with lasers and other optical sources, a comprehensive handbook

Announcements

1

8

14

18

\section{Volume 7, Number 2, June 1981}

"Hazards of heat exposure: A review" FN Dukes-Dobos

"Exposure to acetone: Uptake and elimination in man" E Wigaeus, S Holm, I Åstrand

"Formaldehyde exposure in work and the general environment: Occurrence anc" possibilities for prevention" $R$ Niemelä, $H$ Vainio $\ldots \ldots \ldots \ldots \ldots \ldots \ldots \ldots \ldots$

"Analysis of inorganic fiber concentrations in biological samples by scanning electron microscopy" B Gylseth, $\mathrm{RH}$ Baunan, R Bruun $\ldots \ldots \ldots \ldots \ldots \ldots \ldots \ldots$

"Inorganic fibers in lung tissue from patients with pleural plaques or malignant mesothelioma" B Gylseth, G Mowé, V Skaug, A Wannag .................

"Delivery outcome for women working in the pulp and paper industry" U Blomqvist,

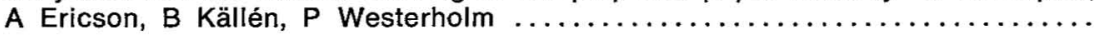

"Relation of soft-tissue sarcoma, malignant lymphoma and colon cancer to phenoxy acids, chlorophenols and other agents" $L$ Hardell $\ldots \ldots \ldots \ldots \ldots \ldots \ldots \ldots$

"Temporal patterns in psychophysiological activation in rotating shift workers A follow-up field study one year after an increase in nighttime work" $K$ Dahlgren

"Long-term adjustment of circadian rhythms to a rotating shiftwork schedule" K Dahl-

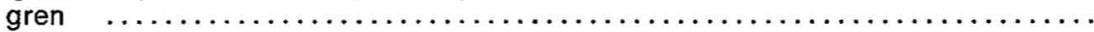

Book review: Developments in occupational medicine ................ 152

Book review: Metals in the environment ....................... 153

Book review: Biological monitoring methods for industrial chemicals .......... 154

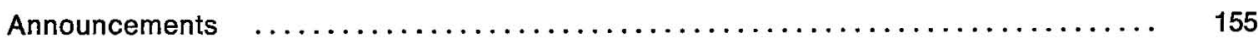




\section{Volume 7, Number 3, September 1981}

"n-Hexane and its toxicologic effects: A review" NK Jørgensen, K-H Cohr ......

"A case-referent study on acute myeloid leukemia, background radiation and exposure to solvents and other agents" U Flodin, L Andersson, C-G Anjou, U-B

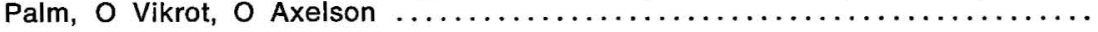

"A cohort study on cancer among workers exposed to an antirust oil" B Järvholm,

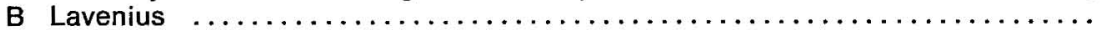

"Occurrence of cancer in a small cohort of asbestos-exposed workers" B Hilt,

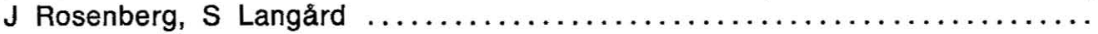

"Topographic and size distribution of asbestos bodies in exposed human lungs"

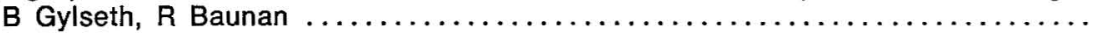

"Age, sleep and irregular workhours: A field study with electroencephalographic recordings, catecholamine excretion and self-ratings" $L$ Torsvall, $T$ Åkerstedt,

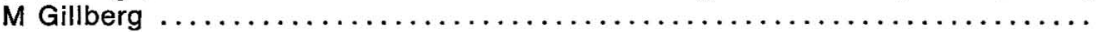

"Testicular function of men occupationally exposed to para-tertiary butyl benzoic acid" MD Whorton, HA Stubbs, A Obrinsky, TH Milby $\ldots \ldots \ldots \ldots \ldots \ldots \ldots$

"Influence of fluoride recovery alumina on the work environment and the health of aluminum potroom workers" $\mathrm{W}$ Eduard, $\mathrm{A}$ Lie $\ldots \ldots \ldots \ldots \ldots \ldots \ldots \ldots \ldots \ldots$

"Polycyclic aromatic hydrocarbons in the work atmosphere: Determination of areaspecific concentrations and job-specific exposure in a vertical pin Søderberg aluminum plant" A Bjørseth, O Bjørseth, PE Fjeldstad .................

"Disappearance of carbon monoxide from the blood: Comparison of the one-exponential and two-exponential elimination models for rat" $\mathrm{K}$ Kurppa ...........

Letter to the Editor: "Re: 'Mutagenic action of isocyanates used in the production of polyurethanes' by $M$ Anderson, M-L Binderup, $P$ Kiel, $H$ Larson, J Maxild. Scand j work environ health 6 (1980) 221-226" WF Diller ...............

Letter to the Editor: "Laryngeal cancer and pickling house vapors" G Ahlborg,

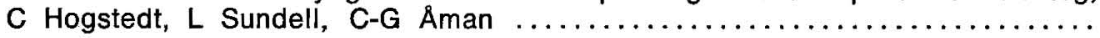

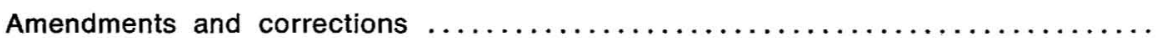

\section{Volume 7, Number 4, December 1981}

"Biological monitoring in the identification of the cancer risk of individuals exposed to chemical carcinogens" H Vainio, M Sorsa, J Rantanen, K Hemminki, A Aitio

"Parkinson's disease and occupational exposure to organic solvents, agricultural chemicals and mercury: A case-referent study" C-G Ohlson, C Hogstedt ....

"Relationship between clinical and electrophysiological findings and indicators of heavy exposure to 2,3,7,8-tetrachlorodibenzo-dioxin" G Filippini, B Bordo, P

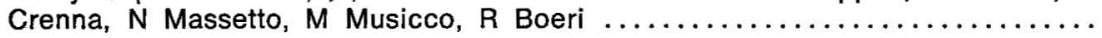

"Hearing damage risk to divers operating noisy tools under water" OI Molvaer,

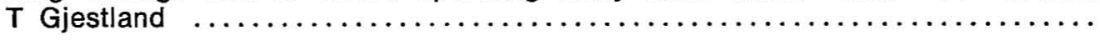

"Accumulation of fibers in the eyes of workers handling man-made mineral fiber

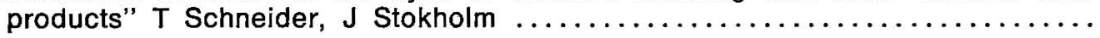

"Chromosome aberrations in cultured human lymphocytes exposed to trivalent and pentavalent arsenic" I Nordenson, A Sweins, L Beckman .................

"Chemosorption sampling and analysis of formaldehyde in air: Influence of recovery during the simultaneous sampling of formaldehyde, phenol, furfural and furfuryl alcohol" K Andersson, C Hallgren, J-O Levin, C-A Nilsson . . . . . . . . . . .

"Emphysema and occupational exposure to industrial pollutants" $H$ Kjuus, $H$ Istad,

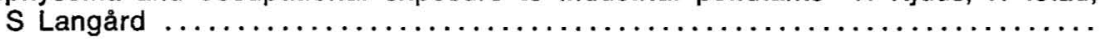

"Occupationally related lead exposure in the general population: A population study of 40-year-old men" P Grandjean, $H$ Hollnagel, NB Olsen . . . . . . . . . . . .

"On the interaction between occupational arsenic exposure and smoking and its relationship to lung cancer" $G$ Pershagen, $S$ Wall, A Taube, $L$ Linnman .....

Letter to the Editor: "Life-threatening pulmonary reaction from car paint containing

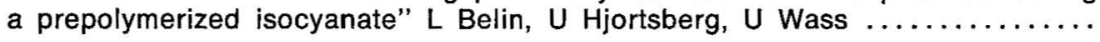

Letter to the Editor: "Sources of variation in fluorometry of zinc protoporphyrin in 
blood" P Grandjean, J Lintrup

Book review: Occupational health risk assessment: A preparatory study of the exposure of welders to toxic substances and the resulting health effects ......

\section{Volume 7, Supplement 1, 1981}

"Carbon monoxide criteria: With reference to effects on the heart, central nervous system and fetus" R Rylander, $\mathrm{J}$ Vesterlund

\section{Volume 7, Supplement 2, 1981}

"Survey of air contaminants from welding" U Ulfvarson

\section{Volume 7, Supplement 3, 1981}

"Health hazards and stress factors in small industry - Prevalence study in the province of Uusimaa with special reference to the type of industry and the occupational title as classifications for the description of occupational health problems" T Vihma

\section{Volume 7, Supplement 4, 1981}

"Proceedings of the US-Finnish joint symposium on occupational safety and health and the third annual NIOSH scientific symposium"

General aspects of occupational health

"Occupational safety and health in the 1980s: Policy options - Historic per-

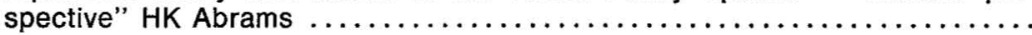

"Job demands and worker health in machine-paced poultry inspection" B Wilkes, L Stammerjohn, $\mathrm{N}$ Lalich

"A cross-sectional medical and industrial hygiene survey of workers exposed to carbon disulfide" $J$ Fajen, B Albright, $S S$ Leffingwell $\ldots \ldots \ldots \ldots \ldots \ldots$

Neurotoxicology

"Neurophysiological findings among workers exposed to organic solvents" AM

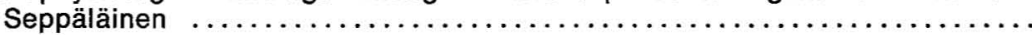

"Epidemiologic design for field studies: Occupational neurotoxicity" JM Melius,

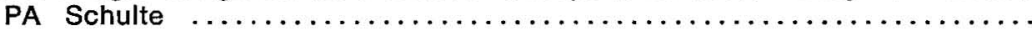

"Neurobehavioral effects of methyl bromide inhalation exposures" WK Anger, JV Setzer, JM Russo, WS Brightwell, RG Wait, BL Johnson ...........

"Behavioral changes after long-term exposure to organic solvents and their mixtures: Determining factors and research results" $\mathrm{K}$ Lindström ........

"Follow-up studies of workers with bladder neuropathy caused by exposure to dimethylaminopropionitrile" EL Baker, DC Christiani, DH Wegman, M Siroky

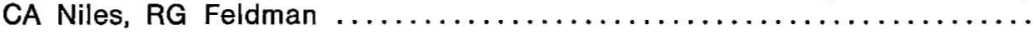

Reproductive effects

"Monitoring genotoxicity in the occupational environment" M Sorsa, K Falck,

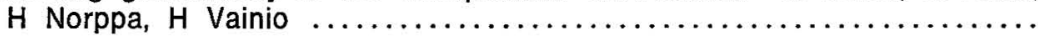

"Testing of selected workplace chemicals for teratogenic potential" BD Hardin, GP Bond, MR Sikov, FD Andrew, RP Beliles, RW Niemeier ............

"Design considerations in pregnancy outcome studies of occupational popula-

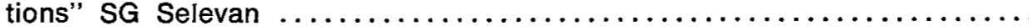

Safety

"Risk assessment and the setting of priorities in occupational health and safety"

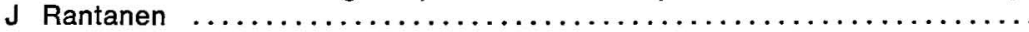


"Epidemiologic principles applied to injury prevention" PJ Coleman ..........

"Work conditions and accidents in three industries" J Saari, J Lahtela .......

"The research-defining Accident Investigation Methodology of the National Institute for Occupational Safety and Health" J Gustin ...............

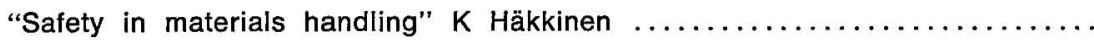

"The determination of effective injury controls for metalcutting lathe operators"

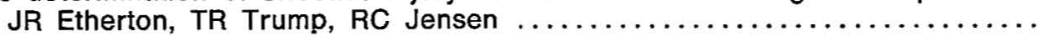

106

109

115

Epidemiology

" 'Negative' results in cohort studies - How to recognize fallacies" S Hernberg

"Developing a national occupational health surveillance system in the United

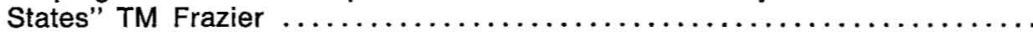

127

"Overview of Finnish epidemiologic studies on occupational cancer" S Tola ..

"Mortality study of workers employed at organochlorine pesticide manufacturing

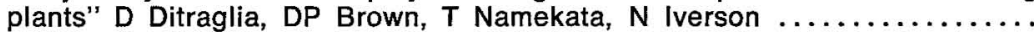

"Lung cancer and other mortality patterns among foundrymen" E Egan-Baum,

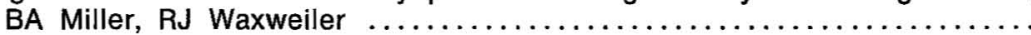

"Mortality among workers in a die-casting and electroplating plant" $M$ Silver stein, $F$ Mirer, D Kotelchuck, B Silverstein, M Bennett ...............

\section{Author index}

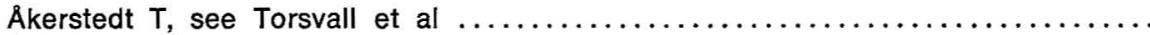

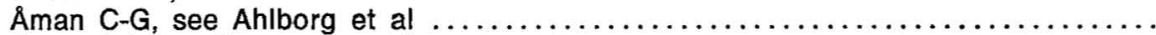

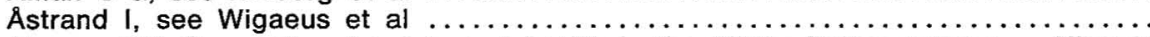

Abrams HK: Occupational safety and health in the 1980s: Policy options - Historic

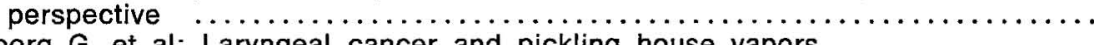

Ahlborg $G$, et al: Laryngeal cancer and pickling house vapors $\ldots \ldots \ldots \ldots \ldots \ldots$

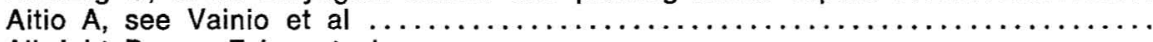

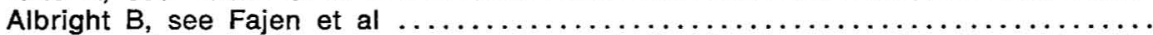

Andersen I, et al: Human response to controlled levels of combinations of sulfur

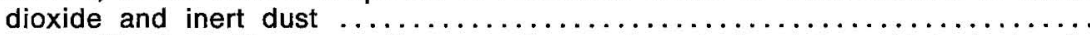

Andersson $\mathrm{K}$, et al: Chemosorption sampling and analysis of formaldehyde in air: Influence of recovery during the simultaneous sampling of formaldehyde, phenol,

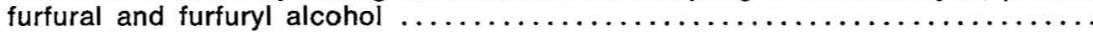

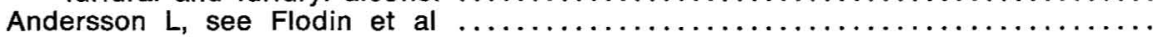

Andrew FD, see Hardin et al . . . . . . . . . . . . . . . . . . . . . . . . . .

Anger WK, et al: Neurobehavioral effects of methyl bromide inhalation exposures

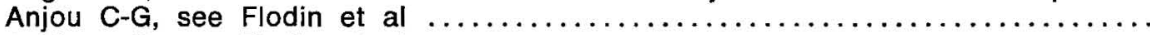

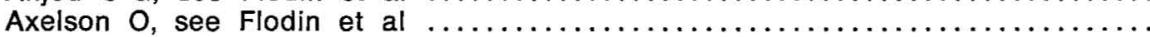

Baker EL, et al: Follow-up studies of workers with bladder neuropathy caused by

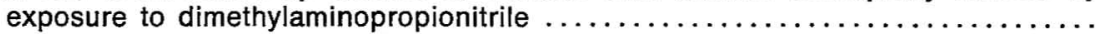

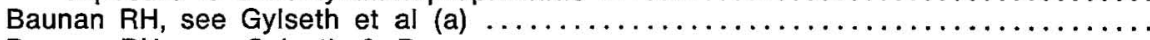

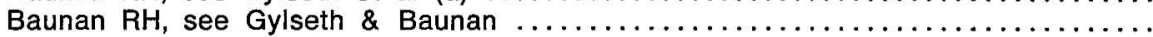

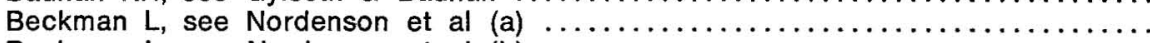

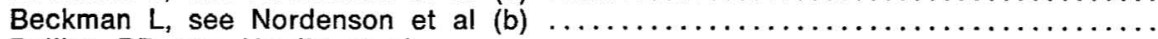

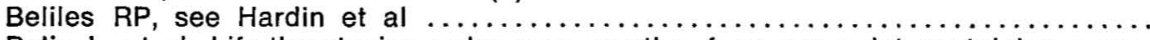

Belin $L$, et al: Life-threatening pulmonary reaction from car paint containing a pre.

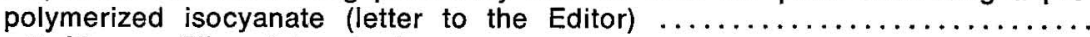

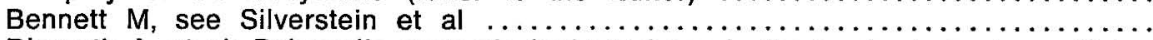

Bjørseth $A$, et al: Polycyclic aromatic hydrocarbons in the work atmosphere: Determination of area-specific concentrations and job-specific exposure in a vertical

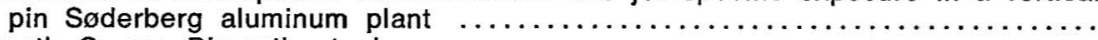

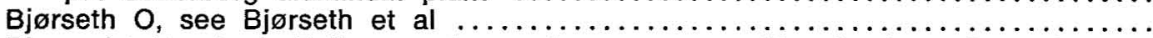

Blomqvist $U$, et al: Delivery outcome for women working in the pulp and paper

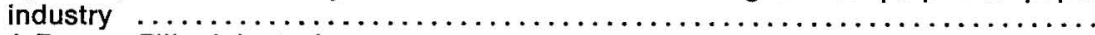

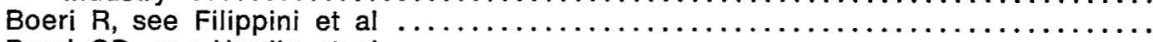

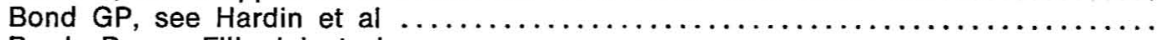

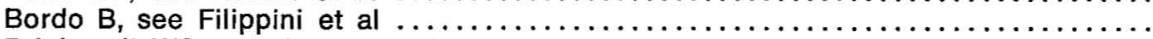

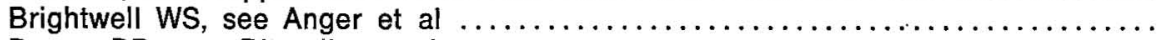

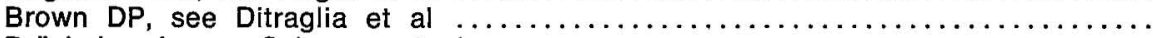

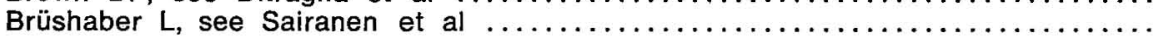

196

239

84

suppl 4,p 7

239

241

suppl 4, p 20

1

282

169

suppl 4, p 66

suppl $4, p 40$

169

169

suppl 4, p 54

101

190

14

277

suppl 4, p 66

310

suppl 4, p 156

223

223

114

257

suppl 4, p 66

257

suppl 4, p 40

suppl 4, p 140

18 